This is an Accepted Manuscript of an article published by Taylor \& Francis in Applied Economics on 23/02/18, available online: https://www.tandfonline.com/doi/abs/10.1080/00036846.2018.1441515?journalCode=raec20 


\title{
IS THE CONSUMPTION-INCOME RATIO STATIONARY IN AFRICAN COUNTRIES? EVIDENCE FROM NEW TIME SERIES TESTS THAT ALLOW FOR STRUCTURAL BREAKS
}

\author{
Sakiru Adebola Solarin \\ Faculty of Business, Multimedia University, \\ 75450 Melaka, Malaysia. Email: sasolarin@ mmu.edu.my \\ Muhammad Shahbaz \\ Montpelier Business School, \\ Montpelier, France Email: shahbazmohd@live.com \\ Chris Stewart, \\ Faculty of Arts and Social Sciences, \\ Kingston University, UK. Email: C.Stewart@kingston.ac.uk
}

\begin{abstract}
This paper examines whether the consumption-income ratio is stationary in 50 African countries. We use the residual augmented least squares (RALS-LM) unit root test that allows for structural breaks developed by Meng et al. (2014). The empirical evidence shows that the consumptionincome ratio is stationary around structural breaks in most (44 out of 50) African countries. This is consistent with the predictions of most economic theory. The general finding of mean reversion implies that (policy) shocks are likely to have only temporary effects on the consumption-income ratio in most African countries.
\end{abstract}

Keywords: consumption-income ratio, African countries, unit root tests, structural breaks JEL Codes: C22, E12, E21 


\section{Introduction}

The general predictions of economic theory are that the consumption-income ratio tends towards a constant, which means that it should be stationary. However, numerous studies that have tested this proposition find evidence that it is not stationary. Determining whether the consumptionincome ratio (and, hence, the savings rate) is stationary is of importance in the light of global imbalances across nations. For example, reduced savings (as well as budget deficits) is one cause of substantive trade deficits. This can raise the rate of interest and cause an appreciation in the exchange rate because foreign capital will likely finance investment demand. Ultimately this can adversely affect exports.

Further, during different stages of the business cycle the way in which consumption (and savings) reacts to income changes may vary, especially in developing countries. In addition, various shocks that have occurred in African countries since the 1970s have forced the consumption-income ratio away from its long-run value (or even shifted that value). In an attempt to allow for this, we utilize unit root tests that can accommodate structural breaks.

Household consumption expenditures account for the largest part of gross domestic product (GDP) in African countries. It absorbed more than 63\% of the continent's GDP in 2014, and in the same year, government expenditures and investment accounted for $15 \%$ and $22 \%$ of GDP, respectively (United Nations, 2016). In most countries, private consumption expenditure is the most stable part of aggregate demand. Investment and exports are known to become volatile when the average propensity to consume (APC) is declining. This causes GDP growth to greatly fluctuate (Abeysinghe and Choy, 2004). Therefore, any attempt to explain the African economy cannot overlook the importance of aggregate consumer behavior, including the behaviour and properties of the APC.

Beyond the relevance of aggregate consumption and the APC in Africa, the relationship between consumption and income is one of the foundations of macroeconomics. The determination of the stochastic properties of the APC is worthwhile because it has significant implications for policy and econometric modelling as well as shedding light on the validity of the predictions of the major theories of consumer behaviour. A non-stationary APC implies that it is not mean reverting such that any shock will have a permanent effect and the APC will not return to its long-run equilibrium. In the case of adverse shocks, the authorities may wish to act to ensure that there is no permanent impact on the APC.

We are not aware of any previous studies that test for a unit root, allowing for structural breaks, in the APC for a large number of African countries - Cerrato et al (2013) apply panel unit root tests to the APC to a sample of 57 nations that includes 7 African countries. We test for the presence of a unit root in the APC whilst taking account of structural breaks for 50 African countries for the period 1970-2014. Hence, our first contribution is to test for a unit root in the APC for the largest number of African countries that has been considered to date. Our second contribution is to apply the Residual Augmented Least Squares (RALS) unit root test of Meng et al. (2014) that allows for the possibility of structural breaks and non-normality. As far as we are aware, we are the first to apply this test to determine the order of integration of the APC for any country. The RALS unit root test accommodates information of non-normality, including 
asymmetry, non-linearity, and fat-tailed distributions (Meng et al. 2014). As indicated above, the application of the RALS unit root test is particularly relevant in our work because it is known that many macroeconomic variables, including the APC, are affected by structural breaks (Cook, 2005). For example, the implementation of financial deregulation policies over several years in many nations can induce structural breaks in the APC due to variations in, for example, liquidity constraints and income uncertainty. Over the past few decades, several Sub-Saharan Africa (SSA) nations have liberalized their financial systems, privatizing many government-owned commercial banks, therefore encouraging more foreign banks to enter and ensuring the purchase of foreign assets by domestic financial corporations (Moyo et al., 2014). Other policies introduced in African countries include the permission of offshore borrowing by domestic residents in the 1990s and the removal of restrictions on portfolio capital inflows. Further, the deregulation of interest rates in this monopolistic environment permitted banks to widen their margins such that real interest rates on bank deposits fell substantially (Pill and Pradhan, 1997). It is therefore appropriate that a method (such as the RALS approach) which allows for the possibility of structural breaks in the APC is employed.

The remainder of the paper is organized as follows. Section 2 reviews the literature while the data and research methodology are discussed in section 3. In section 4 we present and discuss the empirical results. The conclusion of the study and its policy implications are given in section 5 .

\section{Literature review}

Economic theory generally suggests that the APC is stationary. An implication of the Absolute Income Hypothesis (AIH) of Keynes (1936) is that the APC tends towards the marginal propensity to consume (MPC) as income grows. This suggests that the APC should decrease at a decreasing rate as income rises through time, and converge to a constant. Duesenberry's (1949) Relative Income Hypothesis (RIH) implies that the APC will be constant if the income distribution remains constant, however, it will shift if the income distribution shifts (giving rise to possible structural breaks) or if the income distribution is trended the APC will also be trended. However, the equilibrium APC will be constant if the growth rate of consumption does not change according to the habit persistence version of the RIH. Friedman's (1957) Permanent Income Hypothesis (PIH) implies a constant APC if transitory consumption and income as well as the proportionality coefficient remain unchanged over time. Modigliani's (1986) version of the Life Cycle Hypothesis ( $\mathrm{LCH}$ ) implies that a country's saving ratio is unrelated to its percapita income and positively correlated to its rate of income growth. Thus, the aggregate APC will only change if the long-run rate of income growth varies, otherwise it will be constant. Davidson et al. (1978) base their work on the notion that consumption is homogeneous of degree one in income. The implication is that the log of the APC tends towards a constant. Further, because aggregate consumption is not expected to exceed income for a prolonged period or go below zero it is not expected to diverge unboundedly.

Models of consumer behaviour that do not assume certainty equivalence suggest that the APC may be nonstationary if there are changes income uncertainty that induce variations in precautionary savings. For example, Caballero (1990 and 1991), using such models, suggests that higher income uncertainty results in increased precautionary savings and a lower marginal 
propensity to consume (MPC). Further, if labour income and labour income innovations are positively correlated, the MPC will be lower than that predicted by certainty-equivalence models. An implication regarding the APC is that if there are changes in a country's economic environment that cause income uncertainty to change (or shift) this will cause a corresponding change (or shift) in the MPC and, therefore, the APC. This means that changes in a country's income uncertainty implies that its APC may not be stationary or may only be stationary around a shifting mean.

Overall, economic theory indicates that the APC is either constant or tends towards a constant suggesting a theoretical expectation for a stationary aggregate APC. However, the various theories also provide reasons for potential structural shifts in the APC suggesting that the APC may be most appropriately characterized as stationary around possible structural breaks. ${ }^{1}$

Previous tests of the order of integration of the aggregate APC include the following. Sarantis and Stewart (1999) applied the first generation Im et al. (2003) panel unit root test that does not allow for structural breaks to 20 OECD over the period 1957-1994. They found that the APC contains a unit root. Subsequently, Tsionas and Christopoulos (2002) found that the APC was stationary in at least one regime in 14 European Union countries for the period 1960-1999 using a unit root test based on a threshold autoregression that allows for asymmetric adjustment. Cook (2003) applies the Shin and So (2001) unit root test that is more powerful than standard linear adjustment unit root tests, although it does not allow for structural breaks. He finds that the APC is non-stationary using UK quarterly data over the period 1955 - 2001. Using the Lee and Strazicich $(2003,2004)$ unit root tests that allow for up to two structural breaks, Cook (2005) found that the APC was stationary around breaks for 20 OECD countries. Using time-series unit root tests with enhanced power and panel unit root tests that allow for cross-sectional dependence Romero-Ávila (2008) tested the order of integration of the APC in 23 OECD countries over the period 1960 to 2005 . They conclude that the APC contains a unit root. We note that these tests do not allow for structural breaks. Using the same data for 23 OECD countries Romero-Ávila (2009) reinvestigated the unit root hypothesis of the APC. They found, using standard panel unit root tests that do not allow for structural breaks, that the APC appears to be nonstationary. However, when utilizing the Carrion-i-Silvestre et al. (2005) stationarity test that allows for structural breaks the APC is found to be stationary.

Using panel unit root tests that allow for heterogeneous autocorrelation across countries (though not structural breaks) Liao et al. (2011) find that the majority (22 out of 24) of OECD countries' APCs are mean reverting using data over the period 1970 - 2006. Fallahi (2012) examined the unit root properties of the APC in 23 OECD nations over the period 1950-2007 using bootstrapped confidence intervals to enhance the power of the tests. While there is evidence that the APC is stationary in some countries they find that it is non-stationary in most of the countries. Elmi and Ranjbar (2013) considered whether the APC exhibits mean reversion for 16 OECD countries over the period 1960 to 2010. They employed the Becker et al. (2006) test that has stationarity as the null hypothesis and that can control for structural breaks that have not been

${ }^{1}$ Cerrato et al (2013) note that shifts in a range of factors (demographic factors, wealth, inflation, interest rates, income growth, income uncertainty, liquidity constraints and fiscal variables, etc.) can cause the APC to shift, giving rise to structural breaks. 
pre-specified using a flexible Fourier function. They find evident mean reversion of the APC in 12 out of the 16 OECD countries that they consider. Cerrato et al. (2013) tested whether the APC contains a unit root in 24 OECD countries and 33 non-OECD nations (including 7 African countries) over the period 1951-2003. Applying 2 types of panel unit root tests that allow for linear and nonlinear adjustment, respectively, they find evidence that the APC is nonstationary in the majority of nations (78\% of OECD countries and $74 \%$ of non-OECD countries).

The literature review above suggests the following. First, there are relatively few papers that have applied unit root and/or stationarity tests to the aggregate APC. Second, virtually all studies apply the tests to developed nations, especially OECD countries. We could only find one paper that includes unit root tests of African nations' APC and in this paper only 7 African countries are considered. This may partly be due to developed countries' domination of global consumption and income. For instance, the share of western European countries' household final consumption in global consumption was 18\% in 1970 and 12\% in 2014 (World Bank, 2016). The focus on developed countries may also be due to constraints in obtaining sufficient data for developed countries - although such constraints are becoming less binding as time passes. Third, studies that use standard unit root tests generally find the APC to be nonstationary which, given the strong theoretical expectation that they are stationary, raises the suspicion that these findings may be erroneous and due to the low power of unit root tests. This has led many authors to consider methods that are less likely to produce erroneous inference by, for examples, using tests that specify the null as stationarity, allow for nonlinear adjustment, employ panel data and can accommodate structural breaks. The literature suggests that the tests that allow for structural breaks have clearly been the most successful in finding the APC to be stationary, as is expected by theory.

We fill the gap in the literature on developing countries by applying unit root tests to the APC for 50 African countries. We also utilise a method that can accommodate structural breaks given that the previous literature (on mainly developed economies) suggests the need to account for these.

\section{Data and Methodology}

\subsection{Data}

We use annual data on the APC for 50 African countries over the period 1970-2014. ${ }^{2}$ These are derived from household consumption expenditures and GDP provided by the United Nations

\footnotetext{
2 The countries that we consider are: Algeria, Angola, Benin, Botswana, Burkina Faso, Burundi, Cape Verde, Cameroon, Central African Republic, Chad, Comoros, Congo, Cote D'Ivoire, Democratic Republic of the Congo, Djibouti, Egypt, Equatorial Guinea, Gabon, Gambia, Ghana, Guinea, Guinea-Bissau, Kenya, Lesotho, Liberia, Libya, Madagascar, Malawi, Mali, Mauritania, Mauritius, Morocco, Mozambique, Namibia, Niger, Nigeria, Rwanda, Sao Tome and Principe, Senegal, Seychelles, Sierra Leone, Somalia, South Africa, Swaziland, Tanzania, Togo, Tunisia, Uganda, Zambia, Zimbabwe
} 
database. This represents the longest time span available from the database when the series were extracted. These 50 countries are the only ones from Africa with consistent data for all 45 years. $^{3}$

Table-1 reports descriptive statistics for the logarithm of the APC (LAPC). The distribution of LAPC varies greatly across the countries. Of the 50 countries Lesotho (Equatorial Guinea) has the highest average (standard deviation) LAPC while Libya (Senegal) has the lowest average (standard deviation) LAPC. The Jarque-Bera statistics suggest that the null of normality can be rejected in 22 (or 44\%) of the countries using a 10\% level of significance. These countries are Cabo Verde, Central African Republic, Chad, Comoros, Congo Republic, Djibouti, Egypt, Equatorial Guinea, Gabon, Gambia, Ghana, Guinea, Guinea-Bissau, Libya, Mali, Mozambique, Niger, Nigeria, Senegal, Seychelles, Somalia and Tanzania.

A visual plot of aggregate consumption in Africa as a percentage of consumption in the world, Western Europe and the U.S is considered in Figure-1. This shows that the share of African consumption relative to consumption in the rest of the world, consumption in Western Europe and consumption in the U.S has been growing. It also shows that aggregate African consumption has increased from (see the right-hand scale of Figure-1) US\$ 208 billion in 1970 to US\$1,079 in 2014 (United Nations, 2016). The rise in African consumption in both absolute and relative terms has been due to factors such as the population growth rate, a growing number of Africans of middle-class status, the rising pace of urbanization and the move towards digital technologies (Hattingh et al. 2012). There is a rising consumer base in most economies in Africa, steered by the populace in the middle-class. Relative to Latin American countries, there is a higher percentage of young people in the total population in Africa (Deloitte 2014). Overall, this suggests a growing importance of African consumption in the world and that it is timely to examine economic aspects of this continent that have previously been primarily considered in developed countries.

The graph tends to show breaks in the trend of consumption in Africa in the years, 2000, 2006 and 2008. The year 2000 marks the beginning of when many African countries started recording reasonable economic growth, which is partly due to a significant rise in the prices received for primary products. The year 2006 coincided with a significant rise in the continents' trade relationship with China. It resulted in a trebling of trade volumes between China and the African countries from $\$ 10$ billion in 2002 to more than $\$ 40$ billion in 2005 and more than $\$ 50$ billion in 2006 (Zafar, 2007). Hence, within 2006 alone there was a 25\% increase in the trade volume between China and the countries in Africa. China is known to have widespread dealings in several countries in the continent. Chinese companies import oil from Angola and Sudan, Tea from Kenya, Nigeria timber from Central Africa, copper from Zambia as well as gold and platinum from South Africa. The year 2008 coincided with economic uncertainty associated with the decline in demand for raw materials produced in African countries resulting from the slowdown in the European and American markets.

\footnotetext{
${ }^{3}$ The data for Tanzanian is only for the mainland of the country as the dataset for Zanzibar is not available. We have excluded Ethiopia, which is one of the largest countries in the continent, due to a lack of consistent data availability.
} 
In Figure 2 and Figure 3, we plot the 50 African countries' APCs against time (25 nations are depicted in each graph). We have normalized the series, using the z-score method. Whilst the APC declines for many countries, it is also relatively constant or even increasing in some countries. There also appears to be shifts in many of the countries' plots that would be consistent with structural breaks. Hence, vertical lines that correspond to the structural breaks observed from our subsequent econometric analysis have been added to the graphs.

Table-1: Descriptive statistics for the LAPC in African countries

\begin{tabular}{|c|c|c|c|c|c|}
\hline Country & Mean & Std. Dev. & Skewness & Kurtosis & Jarque-Bera \\
\hline Algeria & -0.927 & 0.108 & 0.067 & 1.855 & $2.490(0.288)$ \\
\hline Angola & -0.979 & 0.273 & -0.332 & 1.769 & $3.668(0.160)$ \\
\hline Benin & -0.138 & 0.161 & 0.445 & 1.724 & $4.537(0.103)$ \\
\hline Botswana & -0.719 & 0.255 & 0.573 & 2.078 & $4.054(0.132)$ \\
\hline Burkina Faso & -0.299 & 0.100 & -0.324 & 2.339 & $1.605(0.448)$ \\
\hline Burundi & -0.061 & 0.063 & -0.693 & 2.859 & $3.638(0.162)$ \\
\hline Cabo Verde & -0.478 & 0.054 & 1.543 & 7.349 & $53.306 * * *(0.000)$ \\
\hline Cameroon & -0.329 & 0.043 & 0.222 & 2.381 & $1.086(0.581)$ \\
\hline Central African Republic & -0.383 & 0.193 & -0.902 & 3.102 & $6.125 * *(0.047)$ \\
\hline Chad & -0.109 & 0.248 & 0.107 & 1.291 & $5.560 *(0.062)$ \\
\hline Comoros & -0.365 & 0.144 & 0.209 & 1.354 & $5.404 *(0.067)$ \\
\hline Congo Republic & -1.234 & 0.168 & -1.279 & 4.387 & $15.869 * * *(0.000)$ \\
\hline Cote D'Ivoire & -0.495 & 0.106 & -0.237 & 3.391 & $0.709(0.701)$ \\
\hline Democratic Republic of the Congo & -0.395 & 0.150 & -0.001 & 1.605 & $3.651(0.161)$ \\
\hline Djibouti & -0.186 & 0.182 & -1.157 & 4.577 & $14.704 * * *(0.001)$ \\
\hline Egypt & -0.211 & 0.100 & 0.886 & 3.058 & $5.899 *(0.052)$ \\
\hline Equatorial Guinea & $\begin{array}{l}-0.927 \\
\end{array}$ & 0.446 & -0.689 & 1.725 & $6.614 * *(0.037)$ \\
\hline Gabon & -1.172 & 0.193 & -1.251 & 4.401 & $15.419^{* * * *}(0.000)$ \\
\hline Gambia & -0.125 & 0.131 & -0.338 & 6.226 & $20.367^{* * *}(0.000)$ \\
\hline Ghana & -0.215 & 0.082 & -1.400 & 5.967 & $31.213 * * *(0.000)$ \\
\hline Guinea & -0.049 & 0.088 & -1.033 & 2.987 & $8.005 * *(0.018)$ \\
\hline Guinea-Bissau & -0.230 & 0.228 & -0.819 & 2.080 & $6.615 * *(0.037)$ \\
\hline Kenya & -0.311 & 0.067 & -0.683 & 3.011 & $3.499(0.174)$ \\
\hline Lesotho & 0.239 & 0.150 & 0.327 & 2.270 & $1.802(0.406)$ \\
\hline
\end{tabular}




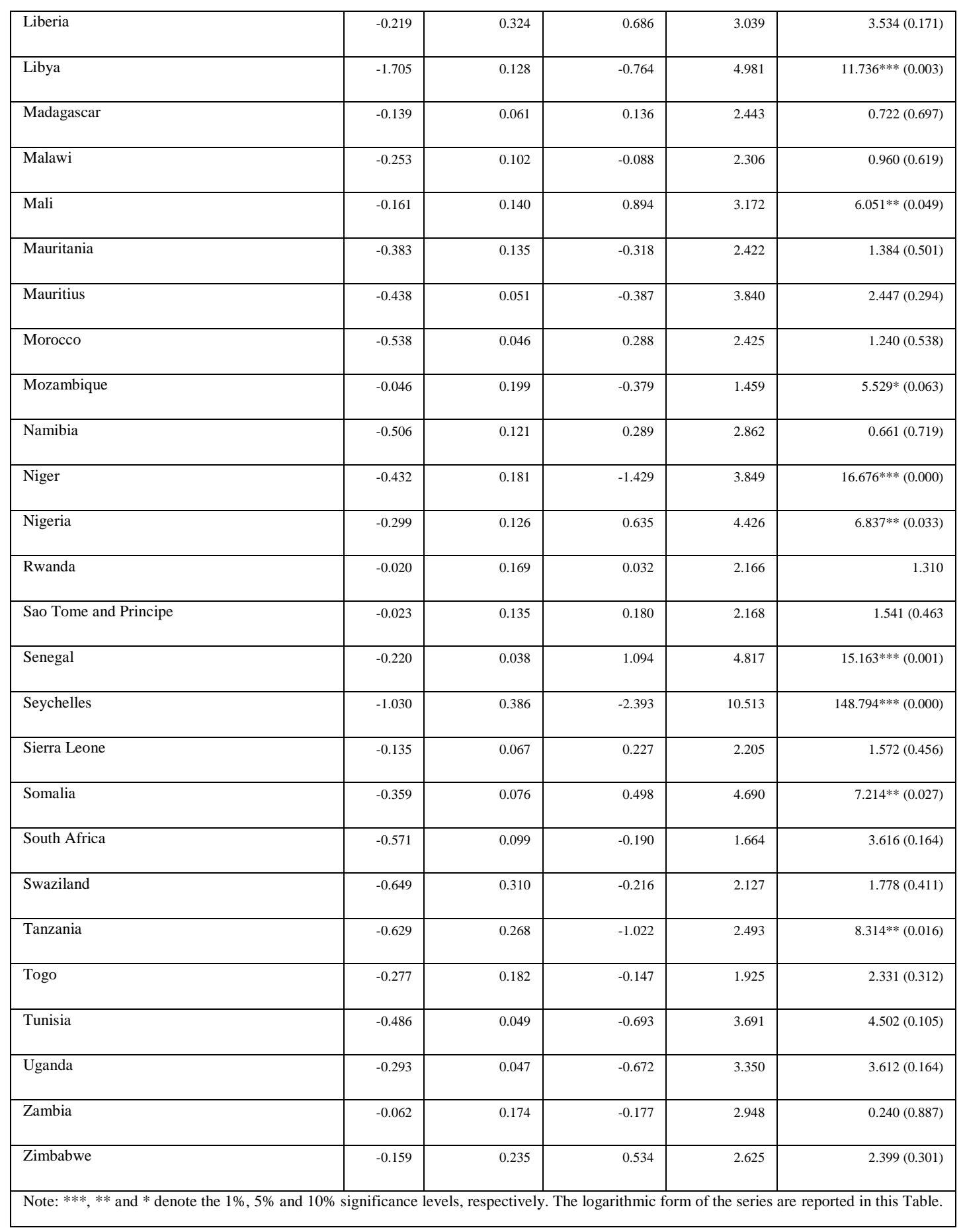


Figure-1: Consumption in Africa

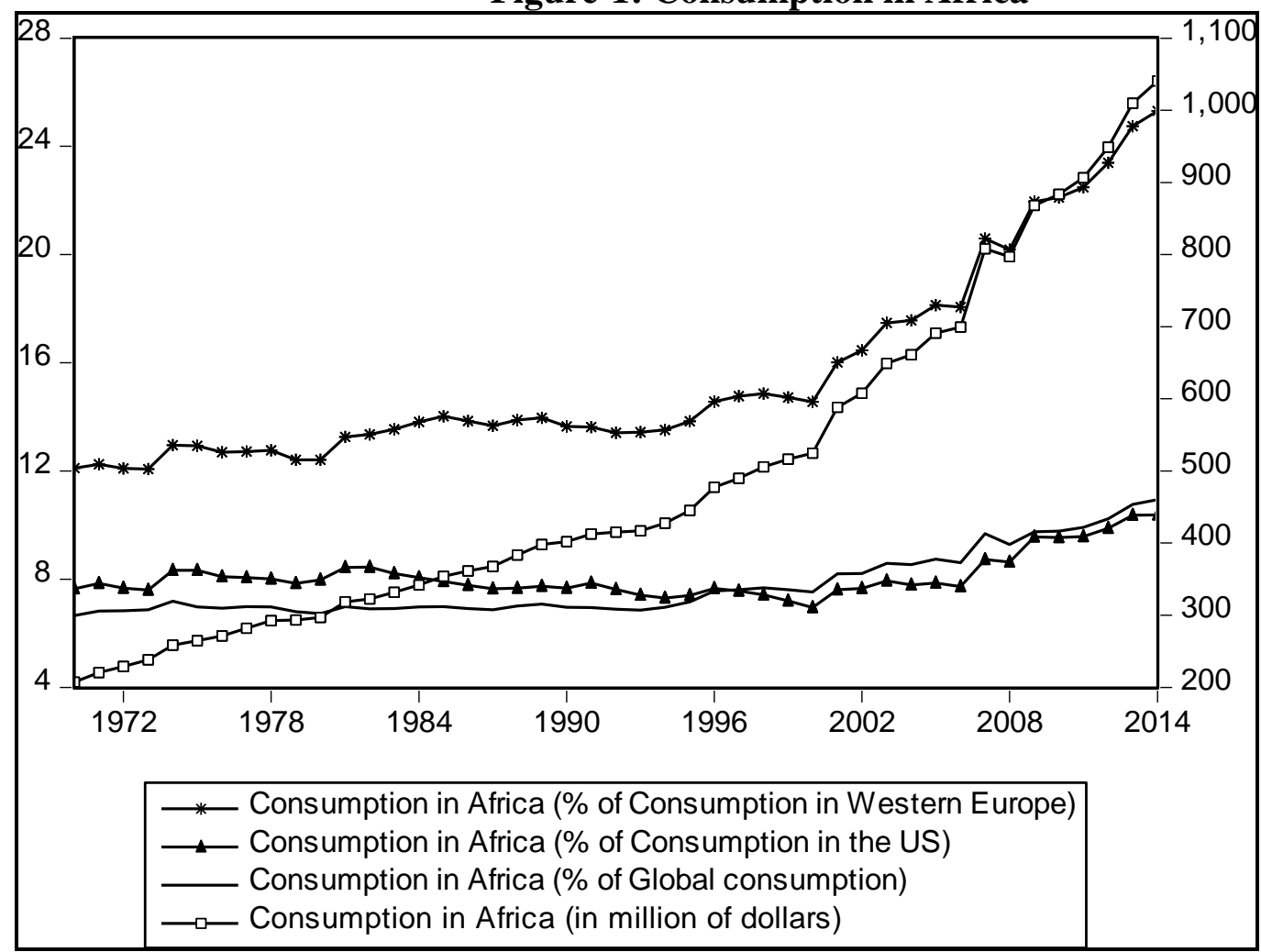


Figure 2: Normalized APC of 25 African countries (Algeria - Liberia)
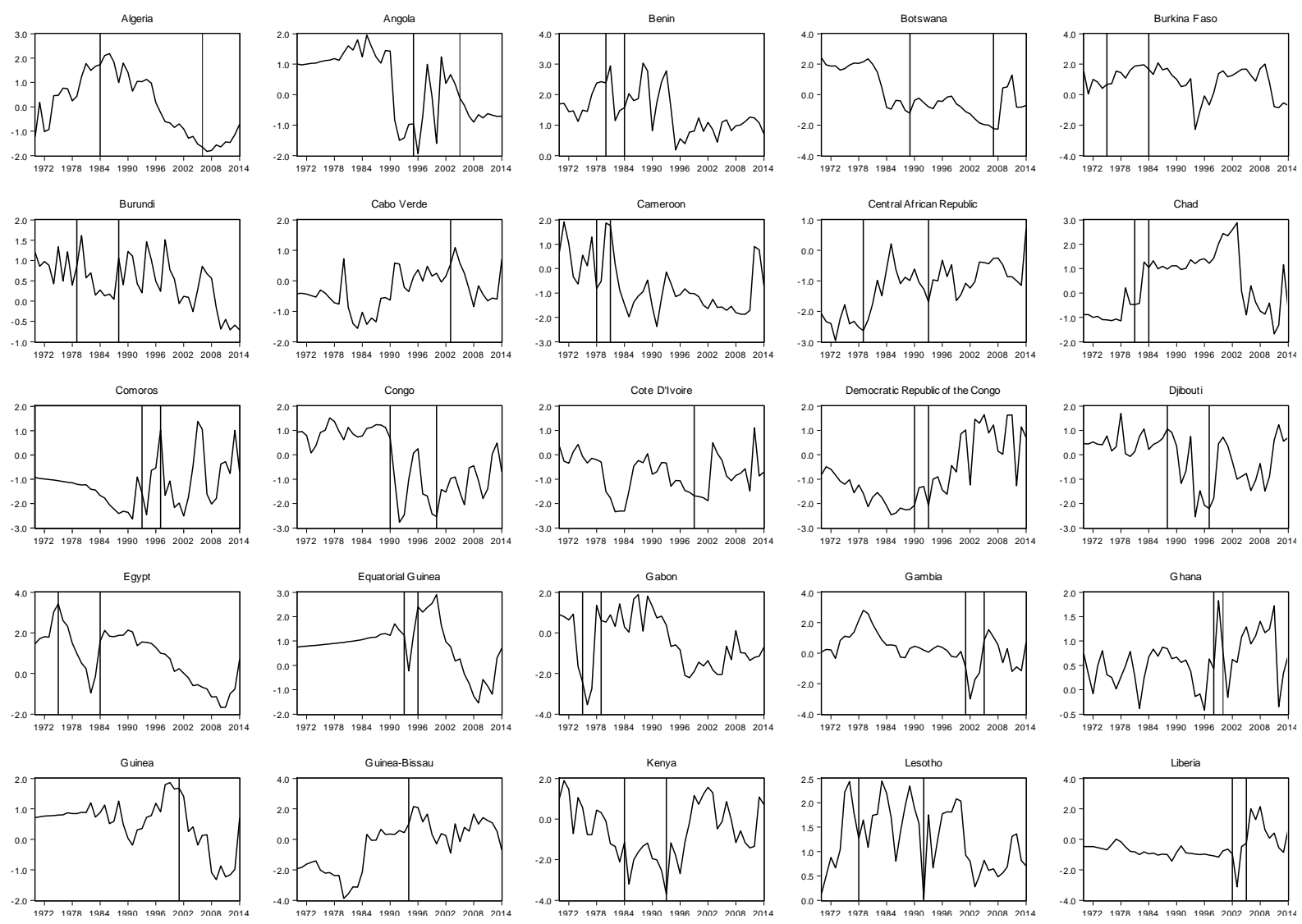
Figure 3: Normalized APC of 25 African countries (Libya - Zimbabwe)

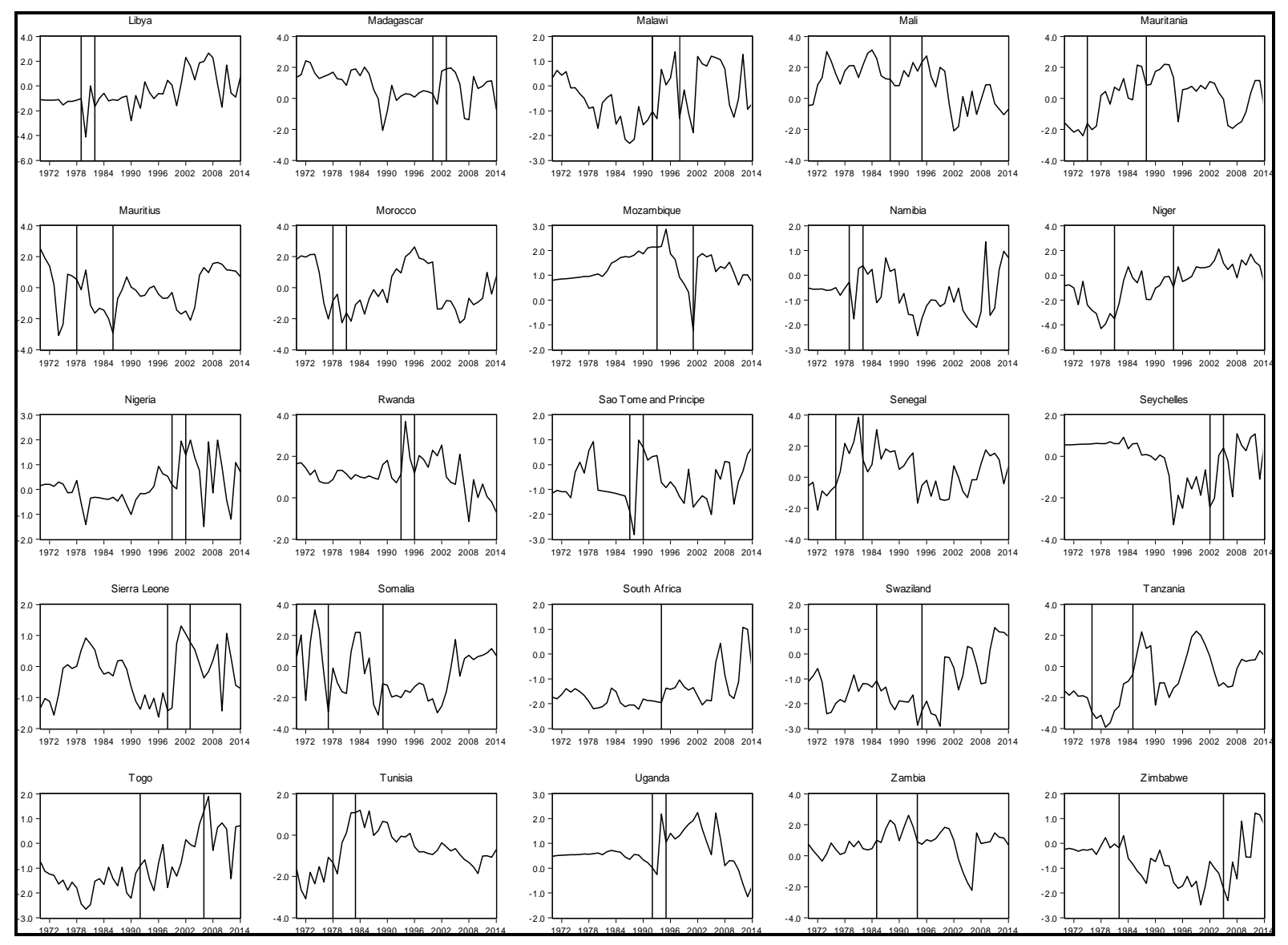

\subsection{Unit root test}

The RALS test of Meng et al. (2014) considers a three-step procedure to identify breaks and test for a unit root. It basically adds an additional step to the two-step LM test of Lee et al. (2012). The first step examines the occurrence of structural breaks in the series, while the second step involves testing for a unit root. To identify and test the significance of breaks, the test adopts a maximum $\mathrm{F}(\max F)$ test. Then, since the location and/or existence of breaks are known following the first step, the unit root test is adopted in the second step. This is important because tests with exogenously determined breaks have greater power than those where breaks are endogenously identified ${ }^{4}$. In the last step, the information on non-normal errors is introduced into the model in a bid to further boost the reliability of the LM statistic.

\footnotetext{
${ }^{4}$ It should be noted that exogenously determined breaks rely on a more restrictive assumption because they assume that the break dates are known beforehand.
} 
The RALS-LM unit root test can be conducted with the following equation:

$$
\Delta y_{t}=\delta^{\prime} \Delta Z_{t}+\phi \tilde{S}_{t-1}^{*}+\sum_{j=1}^{k} d_{j} \Delta \tilde{S}_{t-j}+\gamma \hat{w}_{t}^{\prime}+u_{t}
$$

$y_{t}$ is the logarithm of the APC. $\Delta$ is the difference operator. $k$ is the optimal lag length. $\delta^{\prime}$ contains the coefficients of the exogenous series. $Z_{t}$ is a vector of exogenous variables, which can be

specified as $Z_{t}=\left[1, t, D_{1 t}^{*}, \ldots, D_{R t}^{*}, D T_{1 t}^{*}, \ldots, D T_{R t}^{*}\right]^{\prime}$ where $D_{1 t}^{*}$ is the dummy variable that captures the first change in the intercept and $D T_{1 t}^{*}$ is the dummy variable that captures the first change in the slope. $R$ is the number of breaks. Hence, $D_{1 t}^{*}=1$ for $\mathrm{t} \geq T_{B}+1, i=1, \ldots, R$, and 0 , otherwise, and $D T_{1 t}^{*}=t-T_{B i}$ for $\mathrm{t} \geq T_{B}+1$ and 0 otherwise. $T_{B i}$ captures the breaks' locations (for one country). The null of the unit root is tested using $\phi=0$ and the RALS-LM statistic ( $\tau *$ RALS-LM) is produced through the normal least square method, which is utilised to analyse Eq. (2). $\tilde{S}_{t}^{*}$ denotes the transformed form of the detrended variables, $\tilde{S}_{t}=y_{t}-\tilde{\psi}-Z_{t} \tilde{\delta}$, and $\tilde{\psi}$ is constant. The transformation is required to eliminate the dependency of the test statistic on the nuisance parameter (see Lee et al., 2012 for more details). In the case of the dual shifts in the trend, $R=2$. $\hat{w}_{t}$ is the variable that contains the information of non-normal errors that augments the LM procedure. $\gamma$ is the coefficient of the non-normal errors. In the LM test of Lee et al. (2012), $\gamma=0$ and the t-statistic for $\phi=0$ is denoted by $\tilde{\tau}_{L M}^{*}$. The lagged terms of $\Delta \bar{S}_{t-j}$ are used in the regressions to make sure that there is no serial correlation in the equations.

\section{Empirical findings.}

Table-2 reports the results from the application of the LM and RALS-LM unit root tests with two breaks to the logarithm of the APC (LAPC) for our sample of 50 African countries. We use a $10 \%$ level of significance when drawing all inference for all tests that we apply. The unit root null is rejected in all countries using the LM test and in 45 out of 50 countries using the RALSLM test. The 5 countries where the RALS-LM test indicates non-stationarity are Equatorial Guinea, Ghana, Madagascar, Mozambique and Namibia. Following Meng et al. (2013) we further examine the significance of the identified trend breaks used in the unit root tests reported in Table-2. For 45 countries two trend breaks are found to be significant. However, only one of the two specified structural breaks is significant in the tests applied to the following 5 countries: Cote D'Ivoire, Cape Verde, Guinea, Guinea-Bissau and South Africa.

Given that only one structural break is significant in some countries we also report the LM and RALS-LM unit root tests that specify just one break in Table-3. The null hypothesis of nonstationarity in LAPC is rejected in all the countries using the LM test and in 37 countries using 
the RALS-LM procedure. The countries for which LAPC is non-stationarity according to the latter test are Benin, Cameroon, Central African Republic, Chad, Comoros, Gambia, Kenya, Liberia, Mauritania, Mozambique, Rwanda, Senegal and South Africa. Using both unit root tests the single structural break is significant for all countries. ${ }^{5}$

Table-2: Two-Break LM and RALS-LM Unit Root Tests

\begin{tabular}{|c|c|c|c|c|c|c|c|c|}
\hline \multirow[t]{2}{*}{ Country } & \multirow{2}{*}{$\begin{array}{l}\mathrm{LM} \\
\qquad \tau * \mathrm{LM} \\
\end{array}$} & RALS-LM & \multirow[t]{2}{*}{$\hat{\rho}^{2}$} & \multicolumn{2}{|c|}{$\mathrm{T}_{\mathrm{B}}$} & \multicolumn{3}{|c|}{ RALS-LM critical values } \\
\hline & & $\tau *$ RALS-LM & & $\begin{array}{c}\text { Break } \\
\text { (1) }\end{array}$ & $\begin{array}{l}\text { Break } \\
\text { (2) }\end{array}$ & $1 \%$ & $5 \%$ & $10 \%$ \\
\hline Algeria & $-4.836 * * *[3]$ & $-5.760 * * *[3]$ & 0.719 & 1984 & 2006 & -4.434 & -3.884 & -3.605 \\
\hline Angola & $-6.085 * * *[4]$ & $-6.306^{* * *}[4]$ & 0.767 & 1995 & 2004 & -4.483 & -3.945 & -3.666 \\
\hline Benin & $-6.181 * * *[4]$ & $-6.538 * * *[4]$ & 0.771 & 1980 & 1984 & -4.487 & -3.950 & -3.671 \\
\hline Botswana & $-5.663 * * *[3]$ & $-5.292 * * *[3]$ & 0.999 & 1989 & 2007 & -4.688 & -4.182 & -3.920 \\
\hline Burkina Faso & $-6.065 * * *[0]$ & $-9.102 * * *[0]$ & 0.463 & 1975 & 1984 & -4.100 & -3.525 & -3.217 \\
\hline Burundi & $-5.445 * * *[0]$ & $-5.856^{* * *}[0]$ & 0.746 & 1979 & 1988 & -4.461 & -3.918 & -3.639 \\
\hline Cabo Verde & $-6.136 * * *[3]$ & $-5.249 * * *[3]$ & 0.633 & $1985^{\&}$ & 2003 & -4.343 & -3.780 & -3.489 \\
\hline Cameroon & $-6.322 * * *[1]$ & $-6.421 * * *[1]$ & 0.854 & 1978 & 1981 & -4.573 & -4.040 & -3.767 \\
\hline Central African Republic & $-5.680 * * *[1]$ & $-5.765 * * *[1]$ & 0.896 & 1979 & 1993 & -4.616 & -4.082 & -3.813 \\
\hline Chad & $-5.835 * * *[0]$ & $-7.546^{* * *}[0]$ & 0.575 & 1981 & 1984 & -4.272 & -3.704 & -3.404 \\
\hline Comoros & $-10.641^{* * *}[1]$ & $-10.790 * * *[1]$ & 0.829 & 1993 & 1997 & -4.547 & -4.016 & -3.740 \\
\hline Congo & $-8.298 * * *[3]$ & $-8.028 * * *[3]$ & 0.995 & 1990 & 2000 & -4.686 & -4.178 & -3.916 \\
\hline Cote D'Ivoire & $-5.444 * * *[4]$ & $-5.136 * * *[4]$ & 0.891 & $1988^{\&}$ & 1999 & -4.611 & -4.077 & -3.807 \\
\hline Democratic Republic of the Congo & $-6.301 * * *[0]$ & $-6.450 * * *[0]$ & 0.780 & 1990 & 1993 & -4.496 & -3.962 & -3.683 \\
\hline Djibouti & $-5.887 * * *[1]$ & $-5.232 * * *[1]$ & 0.960 & 1988 & 1997 & -4.661 & -4.144 & -3.879 \\
\hline Egypt & $-6.360 * * *[3]$ & $-6.455 * * *[3]$ & 0.865 & 1975 & 1984 & -4.584 & -4.051 & -3.779 \\
\hline Equatorial Guinea & $-2.484 *[3]$ & $-2.361[3]$ & 0.730 & 1993 & 1996 & -4.445 & -3.898 & -3.619 \\
\hline Gabon & $-4.487 * * *[3]$ & $-4.498^{* *}[3]$ & 0.926 & 1975 & 1979 & -4.638 & -4.111 & -3.844 \\
\hline Gambia & $-5.031 * * *[4]$ & $-5.355^{* * *}[4]$ & 0.828 & 2001 & 2005 & -4.546 & -4.015 & -3.739 \\
\hline Ghana & $-3.522 * * *[0]$ & $-3.496[0]$ & 0.961 & 1998 & 2000 & -4.662 & -4.145 & -3.880 \\
\hline Guinea & $-6.985 * * *[0]$ & $-7.428 * * *[0]$ & 0.798 & 2001 & $2007^{\&}$ & -4.515 & -3.984 & -3.705 \\
\hline Guinea-Bissau & $-6.912 * * *[4]$ & $-7.117 * * *[4]$ & 0.877 & $1978^{\&}$ & 1994 & -4.596 & -4.063 & -3.792 \\
\hline Kenya & $-5.521 * * *[4]$ & $-4.796 * * *[4]$ & 0.780 & 1984 & 1993 & -4.496 & -3.962 & -3.683 \\
\hline
\end{tabular}

${ }^{5}$ Unreported results (available from the authors upon request) from the application of ADF, LM and RALS-LM tests without breaks to all countries' LAPCs indicate rejection of the unit null in 35 countries according to the ADF test and 10 countries using the no-break LM and RALS-LM tests. 


\begin{tabular}{|c|c|c|c|c|c|c|c|c|}
\hline Lesotho & $-6.510 * * *[4]$ & $-7.742 * * *[4]$ & 0.730 & 1978 & 1992 & -4.445 & -3.898 & -3.619 \\
\hline Liberia & $-11.556^{* * *}[0]$ & $-12.167 * * *[0]$ & 0.840 & 2002 & 2005 & -4.558 & -4.027 & -3.752 \\
\hline Libya & $-11.221 * * *[0]$ & $-12.862 * * *[0]$ & 0.705 & 1979 & 1982 & -4.419 & -3.866 & -3.587 \\
\hline Madagascar & $-3.574 * * *[0]$ & $-3.442[0]$ & 0.929 & 2000 & 2003 & -4.640 & -4.114 & -3.847 \\
\hline Malawi & $-5.824 * * *[3]$ & $-5.305 * * *[3]$ & 0.972 & 1992 & 1998 & -4.670 & -4.156 & -3.892 \\
\hline Mali & $-5.611 * * *[3]$ & $-5.928 * * *[2]$ & 0.631 & 1988 & 1995 & -4.341 & -3.778 & -3.486 \\
\hline Mauritania & $-6.280 * * *[1]$ & $-6.004 * * *[1]$ & 0.983 & 1975 & 1988 & -4.677 & -4.167 & -3.903 \\
\hline Mauritius & $-6.418 * * *[3]$ & $-6.520 * * *[3]$ & 0.385 & 1978 & 1986 & -3.966 & -3.380 & -3.063 \\
\hline Morocco & $-5.326 * * *[0]$ & $-5.164 * * *[0]$ & 0.998 & 1978 & 1981 & -4.688 & -4.181 & -3.919 \\
\hline Mozambique & $-4.083 * * *[1]$ & $-3.033[1]$ & 0.604 & 1993 & 2001 & -4.312 & -3.746 & -3.449 \\
\hline Namibia & $-3.960 * * *[0]$ & $-3.705[0]$ & 0.914 & 1979 & 1982 & -4.630 & -4.100 & -3.832 \\
\hline Niger & $-6.805 * * *[3]$ & $-6.644 * * *[3]$ & 0.894 & 1981 & 1994 & -4.614 & -4.080 & -3.810 \\
\hline Nigeria & $-6.336^{* * *}[0]$ & $-5.691 * * *[0]$ & 0.648 & 1999 & 2002 & -4.359 & -3.798 & -3.509 \\
\hline Rwanda & $6.776^{* * *}[0]$ & $-7.786^{* * *}[0]$ & 0.652 & 1993 & 1996 & -4.363 & -3.803 & -3.515 \\
\hline Sao Tome and Principe & $-4.425 * * *[4]$ & $-4.193 * *[4]$ & 0.934 & 1987 & 1990 & -4.643 & -4.119 & -3.852 \\
\hline Senegal & $-7.086^{* * *}[0]$ & $-7.280 * * *[0]$ & 0.857 & 1976 & 1982 & -4.576 & -4.043 & -3.770 \\
\hline Seychelles & $-6.435 * * *[0]$ & $-7.729 * * *[0]$ & 0.563 & 2002 & 2005 & -4.255 & -3.686 & -3.385 \\
\hline Sierra Leone & $-5.723 * * *[4]$ & $-5.958 * * *[4]$ & 0.732 & 1998 & 2003 & -4.447 & -3.901 & -3.622 \\
\hline Somalia & $-10.117 * * *[2]$ & $-14.534 * * *[2]$ & 0.432 & 1977 & 1989 & -4.046 & -3.469 & -3.158 \\
\hline South Africa & $-4.763 * * *[3]$ & $-4.280 * *[3]$ & 0.940 & $1977^{\&}$ & 1992 & -4.648 & -4.125 & -3.859 \\
\hline Swaziland & $-7.121 * * *[1]$ & $-6.597 * * *[1]$ & 0.837 & 1985 & 1995 & -4.555 & -4.024 & -3.748 \\
\hline Tanzania & $-5.536 * * *[1]$ & $-8.377 * * *[1]$ & 0.341 & 1976 & 1985 & -3.891 & -3.286 & -2.964 \\
\hline Togo & $-6.498 * * *[1]$ & $-8.014 * * *[1]$ & 0.651 & 1992 & 2006 & -4.362 & -3.802 & -3.513 \\
\hline Tunisia & $-3.855 * * *[2]$ & $-4.582 * * *[2]$ & 0.673 & 1978 & 1983 & -4.385 & -3.828 & -3.544 \\
\hline Uganda & $-6.598 * * *[3]$ & $-7.485 * * *[3]$ & 0.821 & 1992 & 1995 & -4.539 & -4.008 & -3.731 \\
\hline Zambia & $-6.310 * * *[4]$ & $-7.635^{* * *}[1]$ & 0.548 & 1985 & 1994 & -4.233 & -3.663 & -3.362 \\
\hline Zimbabwe & $-6.273 * * *[4]$ & $-5.657 * * *[4]$ & 0.802 & 1982 & 2005 & -4.519 & -3.989 & -3.710 \\
\hline \multicolumn{9}{|c|}{$\begin{array}{l}\text { Due to the fact that the LM test and RALS-LM test are similar in searching for the break points and the relevant optimal lags, we only report one time to } \\
\text { conserve space. The optimal number of lagged first-differenced term is reported in the parenthesis. TB is the structural break point(s). }{ }^{\text {indicates that the }} \\
\text { trend break is not significant at } 10 \% \text {. The critical values for the LM test are }-3.252,-2.579 \text { and }-2.229 \text { at the } 1 \%, 5 \% \text {, and } 10 \% \text { levels, respectively. All } \\
\text { the critical values are computed, using the codes provided in https://www.dropbox.com/sh/dnjpigmmgfi4otu/AADNU7UVeqWjlNLxsoXn3gZWa?dl=0 } \\
\text { For all the tests, the maximum lag is set at } 4 . * * *, * * \text { and } * \text { denote } 1 \%, 5 \% \text { and } 10 \% \text { significance level. }\end{array}$} \\
\hline
\end{tabular}


Table-3: One-Break LM and RALS-LM Unit Root Tests

\begin{tabular}{|c|c|c|c|c|c|c|c|}
\hline \multirow{2}{*}{ Country } & \multirow{2}{*}{$\begin{array}{l}\mathrm{LM} \\
\tau *_{\mathrm{LM}}\end{array}$} & \multirow{2}{*}{$\begin{array}{l}\text { RALS-LM } \\
\tau * \text { RALS-LM }\end{array}$} & \multirow[t]{2}{*}{$\hat{\rho}^{2}$} & \multirow{2}{*}{$\begin{array}{l}\text { TB } \\
\text { Break }\end{array}$} & \multicolumn{3}{|c|}{ RALS-LM critical values } \\
\hline & & & & & $1 \%$ & $5 \%$ & $10 \%$ \\
\hline Algeria & $-3.767 * * *[3]$ & $-3.533 *[3]$ & 0.973 & 1981 & -4.183 & -3.651 & -3.382 \\
\hline Angola & $-4.005 * * *[4]$ & $-4.940 * * *[4]$ & 0.451 & 1989 & -3.739 & -3.152 & -2.839 \\
\hline Benin & $-3.796 * * *[0]$ & $-2.182[0]$ & 0.609 & $2000^{\&}$ & -3.920 & -3.351 & -3.054 \\
\hline Botswana & $-4.039 * * *[3]$ & $-4.252 * * *[3]$ & 0.932 & 1988 & -4.158 & -3.621 & -3.350 \\
\hline Burkina Faso & $-3.163 * * *[3]$ & $-4.568 * * *$ & 0.565 & 1987 & -3.875 & -3.299 & -2.998 \\
\hline Burundi & $-4.093 * * *[0]$ & $-7.547 * * *[0]$ & 0.282 & 1998 & -3.496 & -2.884 & -2.547 \\
\hline Cabo Verde & $-3.218 * * *[4]$ & $-3.562 *[4]$ & 0.885 & 2003 & -4.130 & -3.586 & -3.312 \\
\hline Cameroon & $-2.922 * *[2]$ & $-2.767[2]$ & 0.553 & 2005 & -3.861 & -3.284 & -2.982 \\
\hline Central African Republic & $-3.156 * * *[1]$ & $-2.695[1]$ & 0.762 & 1993 & -4.045 & -3.487 & -3.205 \\
\hline ser & $-2.491 * *[4]$ & $-2.079[4]$ & 0.570 & 1999 & -3.880 & -3.306 & -3.004 \\
\hline Comoros & $-2.622 * *[3]$ & $-0.979[3]$ & 0.258 & 2007 & -3.456 & -2.833 & -2.494 \\
\hline Congo & $-3.468 * * *[0]$ & $-3.503 *[0]$ & 0.812 & 1997 & -4.091 & -3.530 & -3.248 \\
\hline Cote D`Ivoire & $-3.917 * * *[4]$ & $-3.976^{* *}[4]$ & 0.893 & 1999 & -4.134 & -3.593 & -3.319 \\
\hline Democratic Republic of the Congo & $-4.236^{* * *}[0]$ & $-4.073 * * *[0]$ & 0.666 & 1986 & -3.958 & -3.401 & -3.117 \\
\hline Djibouti & $-3.616^{* * *}[4]$ & $-4.121 * * *[4]$ & 0.809 & 1992 & -4.090 & -3.528 & -3.245 \\
\hline Egypt & $-4.585 * * *[3]$ & $-5.302 * * *[3]$ & 0.706 & 1976 & -3.986 & -3.436 & -3.159 \\
\hline Equatorial Guinea & $-4.704 * * *[0]$ & $-5.829 * * *[0]$ & 0.574 & 1988 & -3.885 & -3.311 & -3.010 \\
\hline Gabon & $-5.801 * * *[3]$ & $-5.049 * * *[3]$ & 0.973 & 1980 & -4.183 & -3.651 & -3.382 \\
\hline Gambia & $-3.762 * * *[3]$ & $-1.903[3]$ & 0.925 & 2001 & -4.153 & -3.616 & -3.345 \\
\hline Ghana & $-5.016 * * *[1]$ & $-4.621 * * *[1]$ & 0.974 & 1997 & -4.183 & -3.652 & -3.383 \\
\hline Guinea & $-4.743 * * *[4]$ & $-5.649 * * *[0]$ & 0.747 & 1999 & -4.029 & -3.473 & -3.193 \\
\hline Guinea-Bissau & $-4.428 * * *[4]$ & $-5.926 * * *[4]$ & 0.587 & 1994 & -3.899 & -3.327 & -3.027 \\
\hline Kenya & $-2.857 * *[4]$ & $-1.952[4]$ & 0.836 & 1992 & -4.104 & -3.549 & -3.269 \\
\hline Lesotho & $-4.287 * * *[3]$ & $-3.402 *[3]$ & 0.929 & 1978 & -4.156 & -3.619 & -3.348 \\
\hline Liberia & $-5.611 * * *[4]$ & $-0.460[4]$ & 0.482 & 2002 & -3.779 & -3.194 & -2.885 \\
\hline Libya & $-6.137 * * *[0]$ & $-3.600 * * *[0]$ & 0.318 & 2000 & -3.552 & -2.951 & -2.618 \\
\hline Madagascar & $-4.028 * * *[1]$ & $-3.522 *[1]$ & 0.941 & 2000 & -4.163 & -3.628 & -3.357 \\
\hline Malawi & $-4.729 * * *[3]$ & $-5.828 * * *[3]$ & 0.800 & 1992 & -4.085 & -3.521 & -3.237 \\
\hline Mali & $-4.233 * * *[1]$ & $-5.792 * *[1]$ & 0.517 & 1999 & -3.821 & -3.239 & -2.934 \\
\hline Mauritania & $-2.938 * *[0]$ & $-3.127[0]$ & 0.916 & 1985 & -4.148 & -3.610 & -3.337 \\
\hline
\end{tabular}




\begin{tabular}{|c|c|c|c|c|c|c|c|}
\hline Mauritius & $-4.287 * * *[0]$ & $-4.625 * * *[0]$ & 0.700 & 1975 & -3.980 & -3.431 & -3.154 \\
\hline Morocco & $-3.072 * *[0]$ & $-3.311 *[0]$ & 0.698 & 1999 & -3.979 & -3.429 & -3.152 \\
\hline Mozambique & $-3.007 * *[0]$ & $-0.077[0]$ & 0.397 & $1994^{\&}$ & -3.669 & -3.078 & -2.757 \\
\hline Namibia & $-4.380 * * *[0]$ & $-4.394 * * *[0]$ & 0.899 & 1986 & -4.137 & -3.597 & -3.324 \\
\hline Niger & $-7.847 * * *[0]$ & $-9.922 * * *[0]$ & 0.692 & 1981 & -3.975 & -3.424 & -3.145 \\
\hline Nigeria & $-5.965 * * *[0]$ & $-8.059 * * *[0]$ & 0.625 & 2000 & -3.931 & -3.365 & -3.072 \\
\hline Rwanda & $-3.639 * * *[4]$ & $-0.543[4]$ & 0.625 & $1993^{\&}$ & -3.931 & -3.365 & -3.072 \\
\hline Sao Tome and Principe & $-3.505 * * *[4]$ & $-3.599 * *[4]$ & 0.551 & 1980 & -3.859 & -3.282 & -2.979 \\
\hline Senegal & $-3.752 * * *[4]$ & $-1.792[4]$ & 0.825 & 1986 & -4.098 & -3.540 & -3.259 \\
\hline Seychelles & $-4.943 * * *[4]$ & $-4.956 * * *[0]$ & 0.791 & 2002 & -4.076 & -3.513 & -3.230 \\
\hline Sierra Leone & $-4.801 * * *[4]$ & $-4.882 * * *[4]$ & 0.642 & 1988 & -3.942 & -3.380 & -3.090 \\
\hline Somalia & $-4.449 * * *[3]$ & $-4.289 * * *[3]$ & 0.515 & 1975 & -3.819 & -3.237 & -2.932 \\
\hline South Africa & $-3.496 * * *[1]$ & $-3.104[1]$ & 0.912 & 1994 & -4.145 & -3.607 & -3.334 \\
\hline Swaziland & $-4.760 * * *[1]$ & $-4.547 * * *[1]$ & 0.890 & 1985 & -4.133 & -3.590 & -3.316 \\
\hline Tanzania & $-4.221 * * *[3]$ & $-4.832 * * *[3]$ & 0.792 & 1981 & -4.077 & -3.514 & -3.230 \\
\hline Togo & $-4.951 * * *[0]$ & $-4.220 * * *[0]$ & 0.987 & 2006 & -4.191 & -3.662 & -3.393 \\
\hline Tunisia & $-3.731 * * *[2]$ & $-3.408 *[2]$ & 0.948 & 1988 & -4.167 & -3.633 & -3.362 \\
\hline Uganda & $-5.058 * * *[0]$ & $-5.034 * * *[0]$ & 0.547 & 2001 & -3.855 & -3.277 & -2.974 \\
\hline Zambia & $-3.247 * * *[0]$ & $-3.928 * *[0]$ & 0.776 & 1991 & -4.060 & -3.499 & -3.217 \\
\hline Zimbabwe & $-5.475 * * *[0]$ & $-5.496 * * *[0]$ & 0.741 & 2005 & -4.023 & -3.468 & -3.188 \\
\hline \multicolumn{8}{|c|}{$\begin{array}{l}\text { Due to the fact that the LM test and RALS-LM test are similar in searching for the break points and the relevant optimal lags, we only } \\
\text { report one time to conserve space. The optimal number of lagged first-differenced term is reported in the parenthesis. TB is the structural } \\
\text { break point(s). \& indicates that the trend break is not significant at } 10 \% \text {. The critical values for the LM test are }-3.252,-2.579 \text { and }-2.229 \text { at } \\
\text { the } 1 \%, 5 \% \text {, and } 10 \% \text { levels, respectively. All the critical values are computed, using the codes provided in } \\
\text { https://www.dropbox.com/sh/dnjpjqmmgfi4otu/AADNU7UVeqWjlNLxsoXn3gZWa?dl=0 }\end{array}$} \\
\hline
\end{tabular}

Since unit root tests are most powerful against the most appropriate alternative hypothesis for the data we will identify the most appropriate test based upon the evidence regarding the significance of structural breaks. Since the unit root tests based upon one break indicate that a structural break is evident in all countries we suggest that that we must assume at least one break for each country and base our inference on unit root tests that allow for at least one break. According to the tests that allow for two structural breaks both of these breaks are significant for 45 countries. Hence, we base our inference on whether LAPC has a unit root or is stationary around a trend with two breaks on the unit root tests that assume two breaks for these 45 countries. For the remaining 5 countries (Cote D'Ivoire, Cabo Verde, Guinea, Guinea-Bissau and South Africa) we base our inference on the tests that allow for one structural break. Whilst the LM test that allows for two breaks rejects the unit root null in all countries the corresponding RALS-LM test does not reject the null for the following 5 countries where there are two evident 
breaks: Equatorial Guinea, Ghana, Madagascar, Mozambique and Namibia. For the 5 countries where only one break is evident the LM test rejects the unit root null in all countries whereas the RALS-LM procedure cannot reject the unit root null in just one country, South Africa, and finds that LAPC is stationary around a single break for the remaining 4 countries. Using all of these results together we cannot discount the existence of a unit root in the LAPC for 6 of the 50 countries (Equatorial Guinea, Ghana, Madagascar, Mozambique, Namibia and South Africa). For 4 countries we find evidence that the LAPC is stationary around a trend with a single break (Cote D'Ivoire, Cabo Verde, Guinea, Guinea-Bissau) while for remaining 40 countries the LAPC is stationary around a trend with two structural breaks.

The foregoing analysis indicates the importance of allowing for structural breaks given that they are evident for all 50 African countries. Since the exclusion of structural breaks when they exist is known to reduce the power of rejecting a false unit root hypothesis it is important that such breaks be accounted for (as we have done) in any such tests to avoid this problem of low power.

The support for the stationarity of LAPC around structural breaks is consistent with the work of Cook (2005), Romero-Ávila (2009) and Elmi and Ranjbar (2013) who apply unit root tests that allow for breaks to data from OECD countries.

Although real consumption has greatly increased over the years in African countries, there has generally been a corresponding increase in real GDP. The changes in factors such as the inflation rate and the interest rate tend to have affected both consumption and income (Solarin and Anoruo, 2015) and have therefore had little impact on the APC in the long-run although there may be short-run divergences that possibly manifest themselves as structural breaks. Further, the growing availability of consumer credit, allowing households to increase living standards, may also have shifted the APC causing the breaks that we have found to be evident. Nevertheless, consumption and income generally do not appear to diverge (despite these breaks) given our finding that the LAPC of most African countries is stationary around structural breaks.

Based on the two-break unit root tests, 95 significant structural breaks are identified with 27 (28\%) breaks occurring in the 1980s. This was a period in which several African countries witnessed very poor economic growth that led to their categorisation as underdeveloped (Solarin and Anoruo, 2015). The slow growth during this period was due to factors that include: poorly developed financial systems, incessant conflicts, low educational attainment, huge black-market exchange-rate premia and substantial budget deficits (Easterly and Levine, 1997). Another 31 (32\%) breaks are located in the 1990s, which was a period when many African countries started to experience high economic growth rates. The causes of the high economic growth rates in this period include economic reforms and the return to democracy. 
Table-4: Analysis of the Break Dates

\begin{tabular}{|c|c|c|c|c|c|c|c|c|}
\hline Country & First Break & $\begin{array}{r}\text { Kind of } \\
\text { Shock }\end{array}$ & Duration & Anticipation & $\begin{array}{r}\text { Second } \\
\text { Break }\end{array}$ & Kind of Shock & Duration & $\begin{array}{r}\text { Anticipatio } \\
\mathrm{n}\end{array}$ \\
\hline Algeria & 1984 & Food crisis & 1984-1988 & Unexpected & 2006 & $\begin{array}{c}\text { Oil prices } \\
\text { Increase }\end{array}$ & $\begin{array}{r}2006- \\
2008\end{array}$ & Unexpected \\
\hline Angola & 1995 & $\begin{array}{r}\text { Fragile } \\
\text { Periods of } \\
\text { Peace }\end{array}$ & 1995-1998 & Unexpected & 2004 & Tax Reform & $\begin{array}{r}2004- \\
2011\end{array}$ & Expected \\
\hline Benin & 1980 & $\begin{array}{r}\text { New } \\
\text { Democratic } \\
\text { Dispensatio } \\
\mathrm{n}\end{array}$ & 1980-1984 & Expected & 1984 & $\begin{array}{r}\text { New } \\
\text { Democratic } \\
\text { Dispensation }\end{array}$ & $\begin{array}{r}1984- \\
1991\end{array}$ & Expected \\
\hline Botswana & 1989 & $\begin{array}{r}\text { Tax } \\
\text { reforms }\end{array}$ & 1989-1992 & Expected & 2007 & $\begin{array}{r}\text { Global } \\
\text { Financial } \\
\text { Crisis }\end{array}$ & $\begin{array}{r}2007- \\
2008\end{array}$ & Unexpected \\
\hline Burkina Faso & 1975 & $\begin{array}{r}\text { War with } \\
\text { Mali }\end{array}$ & $1974-1975$ & Unexpected & 1984 & Tax Reforms & $\begin{array}{r}1984- \\
1987\end{array}$ & Unexpected \\
\hline Burundi & 1979 & $\begin{array}{r}\text { Major } \\
\text { Outbreak of } \\
\text { Dysentery }\end{array}$ & 1979-1988 & Unexpected & 1988 & $\begin{array}{r}\text { Brief Civil } \\
\text { Conflict }\end{array}$ & $\begin{array}{r}1988- \\
1988\end{array}$ & Unexpected \\
\hline Cape Verde & 2003 & $\begin{array}{r}\text { Privatisatio } \\
\mathrm{n} \text { of State } \\
\text { Utilities }\end{array}$ & 2003-Date & Expected & & & & \\
\hline Cameroon & 1978 & $\begin{array}{r}\text { Oil } \\
\text { Exploitatio } \\
\mathrm{n} \text { Started }\end{array}$ & 1978-Date & Expected & 1981 & $\begin{array}{l}\text { Start of the } \\
\text { Excessive } \\
\text { Indebtedness }\end{array}$ & $\begin{array}{c}\text { 1981- } \\
\text { Date }\end{array}$ & Unexpected \\
\hline $\begin{array}{r}\text { Central African } \\
\text { Republic }\end{array}$ & 1979 & $\begin{array}{r}\text { Overthrown } \\
\text { of } \\
\text { Governmen } \\
t\end{array}$ & 1979-1981 & Unexpected & 1993 & $\begin{array}{r}\text { Return to } \\
\text { Democracy }\end{array}$ & $\begin{array}{r}1993- \\
2003\end{array}$ & Expected \\
\hline Chad & 1981 & $\begin{array}{r}\text { End of a } \\
\text { Phase of } \\
\text { Libya-Chad } \\
\text { Conflict }\end{array}$ & $1980-1981$ & Expected & 1984 & Drought & $\begin{array}{r}1984- \\
1985\end{array}$ & Unexpected \\
\hline Comoros & 1993 & Elections & 1993-1993 & Expected & 1997 & $\begin{array}{r}\text { Internal } \\
\text { Conflict over } \\
\text { Secession }\end{array}$ & $\begin{array}{r}1997- \\
2001\end{array}$ & Expected \\
\hline Congo & 1990 & $\begin{array}{r}\text { Multiparty } \\
\text { Politics } \\
\text { Started }\end{array}$ & 1990-1997 & Expected & 2000 & $\begin{array}{r}\text { More } \\
\text { Economic } \\
\text { Freedom }\end{array}$ & $\begin{array}{r}2000- \\
\text { Date }\end{array}$ & Expected \\
\hline Cote D'Ivoire & 1999 & $\begin{array}{r}\text { Tax } \\
\text { Reforms }\end{array}$ & 1999-date & Expected & & & & \\
\hline $\begin{array}{r}\text { Democratic Republic } \\
\text { of the Congo }\end{array}$ & 1990 & $\begin{array}{r}\text { Reduction } \\
\text { in World } \\
\text { Bank } \\
\text { Lending }\end{array}$ & 1990-1997 & Unexpected & 1993 & $\begin{array}{l}\text { Internal } \\
\text { Conflict }\end{array}$ & $\begin{array}{r}1993- \\
1997\end{array}$ & Unexpected \\
\hline Djibouti & 1988 & $\begin{array}{r}\text { Border } \\
\text { Conflict } \\
\text { Between } \\
\text { Ethiopia } \\
\text { and Eritrea }\end{array}$ & $1988-2000$ & Unexpected & 1997 & Privatization & $\begin{array}{r}1997- \\
\text { Date }\end{array}$ & Expected \\
\hline Egypt & 1975 & $\begin{array}{r}\text { Tax } \\
\text { Reforms }\end{array}$ & $1975-1981$ & Expected & 1984 & $\begin{array}{r}\text { Parliamentary } \\
\text { Election }\end{array}$ & $\begin{array}{r}1984- \\
1987\end{array}$ & Expected \\
\hline Equatorial Guinea & 1993 & $\begin{array}{l}\text { Parliamenta } \\
\text { ry Election }\end{array}$ & 1993-1999 & Expected & 1996 & $\begin{array}{r}\text { Large Scale } \\
\text { Oil Production }\end{array}$ & 1996- & Unexpected \\
\hline
\end{tabular}




\begin{tabular}{|c|c|c|c|c|c|c|c|c|}
\hline & & & & & & Starts & & \\
\hline Gabon & 1975 & $\begin{array}{r}\text { Joining } \\
\text { OPEC }\end{array}$ & 1975-1994 & Expected & 1979 & $\begin{array}{r}\text { Presidential } \\
\text { Election }\end{array}$ & $\begin{array}{r}1979- \\
1986\end{array}$ & Expected \\
\hline Gambia & 2001 & $\begin{array}{r}\text { Tax } \\
\text { Reforms }\end{array}$ & 2001-date & Expected & 2005 & $\begin{array}{r}\text { New } \\
\text { Restrictive } \\
\text { Legislation }\end{array}$ & $\begin{array}{r}2005- \\
2005\end{array}$ & Unexpected \\
\hline Ghana & 1998 & $\begin{array}{r}\text { Tax } \\
\text { Reforms }\end{array}$ & 1998-Date & Expected & 2000 & Tax Reforms & $\begin{array}{r}2000- \\
\text { Date }\end{array}$ & Expected \\
\hline Guinea & 2001 & $\begin{array}{r}\text { Tax } \\
\text { Reforms }\end{array}$ & 2001-date & Expected & & & & \\
\hline Guinea-Bissau & 1994 & $\begin{array}{r}\text { First Multi- } \\
\text { Party } \\
\text { Election }\end{array}$ & 1994-1999 & Expected & & & & \\
\hline Kenya & 1984 & Drought & 1984-1985 & Unexpected & 1993 & Tax Reform & $\begin{array}{r}1993- \\
1995\end{array}$ & Unexpected \\
\hline Lesotho & 1978 & $\begin{array}{r}\text { Debt } \\
\text { written off } \\
\text { by UK }\end{array}$ & 1978 & Unexpected & 1992 & Tax Reform & $\begin{array}{r}1992- \\
\text { Date }\end{array}$ & Unexpected \\
\hline Liberia & 2002 & $\begin{array}{l}\text { Internal } \\
\text { Conflict }\end{array}$ & $2002-2003$ & Expected & 2005 & $\begin{array}{r}\text { Presidential } \\
\text { Election }\end{array}$ & $\begin{array}{r}2005- \\
2011\end{array}$ & Expected \\
\hline Libya & 1979 & $\begin{array}{r}\text { Increase in } \\
\text { oil Prices }\end{array}$ & 1979-1980 & Unexpected & 1982 & Embargo & $\begin{array}{r}1982- \\
1999\end{array}$ & Unexpected \\
\hline Madagascar & 2000 & Floods & $2000-2000$ & Unexpected & 2003 & Political Crisis & $\begin{array}{r}2002- \\
2003\end{array}$ & Expected \\
\hline Malawi & 1992 & $\begin{array}{r}\text { Tax } \\
\text { Reforms }\end{array}$ & 1992-1995 & Expected & 1998 & Tax Reforms & $\begin{array}{r}1998- \\
1999\end{array}$ & Expected \\
\hline Mali & 1988 & $\begin{array}{r}\text { Structural } \\
\text { Reform } \\
\text { Policies } \\
\text { (Privatisatio } \\
\mathrm{n} \text { and } \\
\text { Liberalisati } \\
\text { on) }\end{array}$ & $1988-1998$ & Expected & 1995 & Tax Reforms & $\begin{array}{r}1995- \\
\text { Date }\end{array}$ & Expected \\
\hline Mauritania & 1975 & $\begin{array}{r}\text { Madrid } \\
\text { Agreement } \\
\text { (Spanish } \\
\text { Sahara } \\
\text { divided } \\
\text { between } \\
\text { Morocco } \\
\text { and } \\
\text { Mauritania }\end{array}$ & 1975-Date & Expected & 1988 & Flooding & $\begin{array}{r}1988- \\
1988\end{array}$ & Unexpected \\
\hline Mauritius & 1978 & $\begin{array}{r}\text { Tax } \\
\text { Reforms }\end{array}$ & 1978-1978 & Unexpected & 1986 & $\begin{array}{r}\text { Liberalisation } \\
\text { of the } \\
\text { Economy }\end{array}$ & $\begin{array}{r}1986- \\
\text { Date }\end{array}$ & Expected \\
\hline Morocco & 1978 & $\begin{array}{r}\text { Stabilizatio } \\
\mathrm{n} \text { Triennial } \\
\text { Plan }\end{array}$ & 1978-1980 & Expected & 1981 & Drought & $\begin{array}{r}1981- \\
1993\end{array}$ & Unexpected \\
\hline Mozambique & 1993 & $\begin{array}{r}\text { Tax } \\
\text { Reforms }\end{array}$ & 1993-Date & Expected & 2001 & Flood & $\begin{array}{r}2000- \\
2001\end{array}$ & Unexpected \\
\hline Namibia & 1979 & $\begin{array}{r}\text { Namibian } \\
\text { War of } \\
\text { Independe } \\
\text { nce }\end{array}$ & $1979-1990$ & Unexpected & 1982 & $\begin{array}{r}\text { Constitutional } \\
\text { Principles } \\
\text { Agreed }\end{array}$ & $\begin{array}{r}1982- \\
1990\end{array}$ & Expected \\
\hline Niger & 1981 & Food Crisis & 1981-1983 & Unexpected & 1994 & $\begin{array}{l}\text { End of Civil } \\
\text { Unrest With }\end{array}$ & 1990- & Expected \\
\hline
\end{tabular}




\begin{tabular}{|c|c|c|c|c|c|c|c|c|}
\hline & & & & & & $\begin{array}{r}\text { Tuareg } \\
\text { Rebellion }\end{array}$ & 1994 & \\
\hline Nigeria & 1999 & $\begin{array}{r}\text { Return to } \\
\text { Democratic } \\
\text { Rule }\end{array}$ & 1999-date & Expected & 2002 & $\begin{array}{r}\text { Several Cases } \\
\text { of Civil Unrest }\end{array}$ & $\begin{array}{r}2002- \\
2002\end{array}$ & Unexpected \\
\hline Rwanda & 1993 & $\begin{array}{r}\text { Peace } \\
\text { Agreement } \\
\text { with } \\
\text { Rwandan } \\
\text { Patriotic } \\
\text { Front }\end{array}$ & $1990-1993$ & Expected & 1996 & $\begin{array}{r}\text { Invasion of } \\
\text { Congo DR by } \\
\text { Rwanda }\end{array}$ & $\begin{array}{r}1996- \\
1997\end{array}$ & Unexpected \\
\hline $\begin{array}{r}\text { Sao Tome and } \\
\text { Principe }\end{array}$ & 1987 & $\begin{array}{r}\text { First } \\
\text { Structural } \\
\text { Adjustment } \\
\text { Programme }\end{array}$ & 1987-1989 & Expected & 1990 & $\begin{array}{r}\text { Second } \\
\text { Structural } \\
\text { Adjustment } \\
\text { Programme }\end{array}$ & $\begin{array}{r}1990- \\
1992\end{array}$ & Expected \\
\hline Senegal & 1976 & $\begin{array}{r}\text { Multi-party } \\
\text { Democracy } \\
\text { Starts }\end{array}$ & 1976-Date & Expected & 1982 & $\begin{array}{r}\text { Civil Conflict } \\
\text { Start }\end{array}$ & $\begin{array}{r}1982- \\
\text { Date }\end{array}$ & Unexpected \\
\hline Seychelles & 2002 & $\begin{array}{r}\text { Parliamenta } \\
\text { ry Election }\end{array}$ & $2002-2002$ & Expected & 2005 & Tax Reforms & $\begin{array}{l}2005- \\
\text { Date }\end{array}$ & Expected \\
\hline Sierra Leone & 1998 & $\begin{array}{r}\text { Foreign } \\
\text { Forces } \\
\text { Invade the } \\
\text { Country }\end{array}$ & 1998-1998 & Expected & 2003 & $\begin{array}{r}\text { Reduction In } \\
\text { Foreign Aid }\end{array}$ & $\begin{array}{r}2003- \\
2003\end{array}$ & Unexpected \\
\hline Somalia & 1977 & $\begin{array}{c}\text { War with } \\
\text { Ethiopia }\end{array}$ & $1977-1978$ & Unexpected & 1989 & Insurgency & $\begin{array}{r}1989- \\
1990 \\
\end{array}$ & Unexpected \\
\hline South Africa & 1994 & $\begin{array}{r}\text { End of } \\
\text { Apartheid } \\
\end{array}$ & 1994-Date & Expected & & & & \\
\hline Swaziland & 1985 & $\begin{array}{r}\text { Depreciatio } \\
n \text { of the } \\
\text { Currency }\end{array}$ & 1985-Date & Unexpected & 1995 & Tax Reforms & $\begin{array}{r}1995- \\
1995\end{array}$ & Expected \\
\hline Tanzania & 1976 & Tax Reform & $1976-1985$ & Expected & 1985 & Tax Reform & $\begin{array}{r}1985- \\
1985 \\
\end{array}$ & Expected \\
\hline Togo & 1992 & $\begin{array}{r}\text { Political } \\
\text { Unrest } \\
\end{array}$ & 1992-1993 & Unexpected & 2006 & Tax Reforms & $\begin{array}{r}2006- \\
\text { Date }\end{array}$ & Expected \\
\hline Tunisia & 1978 & $\begin{array}{r}\text { Labour } \\
\text { Riots } \\
\end{array}$ & $1978-178$ & Unexpected & 1983 & Bread Riots & $\begin{array}{r}1983- \\
1984 \\
\end{array}$ & Unexpected \\
\hline Uganda & 1992 & $\begin{array}{r}\text { High } \\
\text { Inflation } \\
\text { rate }(52 \%) \\
\end{array}$ & $1992-1992$ & Expected & 1995 & $\begin{array}{r}\mathrm{New} \\
\text { Constitution }\end{array}$ & $\begin{array}{r}1995- \\
\text { Date }\end{array}$ & Expected \\
\hline Zambia & 1985 & $\begin{array}{r}\text { Tax } \\
\text { Reforms } \\
\end{array}$ & $1985-1986$ & Expected & 1994 & Tax Reforms & $\begin{array}{r}1994- \\
\text { Date }\end{array}$ & Expected \\
\hline Zimbabwe & 1982 & $\begin{array}{r}\text { Civil } \\
\text { conflict }\end{array}$ & $1982-1987$ & Expected & 2005 & $\begin{array}{r}\text { Parliamentary } \\
\text { Election }\end{array}$ & $\begin{array}{r}2005- \\
2005\end{array}$ & Expected \\
\hline
\end{tabular}

An analysis of the identified structural breaks is summarized in Table-4. It is noted that about 24 breaks (or $25 \%$ of the total breaks) are associated with the tax reforms in Table-4. The observed breaks are not consistent with Ricardian equivalence, which argues that tax changes do not affect current consumption. According to Ricardian equivalence, the substitution of a budget deficit for current taxes has the same consequence on aggregate demand. A reduction in taxes by the government results into a budget deficit with the possibility of future tax increases. According to the hypothesis, rational consumers are aware that these future taxes have a present value equal to the incurred debt. The consumers therefore see through the intertemporal veil, saving additional disposable income to pay the future taxes instead of increasing their consumption (Mosikari and Eita, 2017). 
Our findings do not appear to follow any identifiable pattern according to country characteristics. For example, the countries with stationary LAPCs include non-oil rich countries (such as Kenya and Lesotho) as well as oil-rich nations (such as Nigeria and Libya). Burundi and the Democratic Republic of Congo, which experienced prolonged internal strife, have stationary LAPCs like peaceful nations such as Zambia. Fragile states (Jones, 2013) such as Guinea, Guinea Bissau, Liberia, Sierra Leone, Somalia and Togo and non-fragile states (Benin and Morocco) all have stationary LAPCs. Whilst in terms of size, relatively large countries (Morocco and Nigeria) and small countries (Benin and Lesotho) all have stationary LAPCs.

Table-5: Panel LM Unit Root Analysis

\begin{tabular}{|l|c|c|c|}
\hline Panels & No Break & Single Break & Double Break \\
\hline East Africa & $-2.190^{* *}$ & -0.9876 & $-2.1561^{* *}$ \\
\hline West Africa & $-1.7815^{*}$ & $-34.035^{*}$ & $-11.2451^{*}$ \\
\hline Middle Africa & -0.6857 & $-28.908^{*}$ & $-10.876^{*}$ \\
\hline South Africa & -1.0918 & $-20.808^{*}$ & $-7.767^{*}$ \\
\hline North Africa & $-10.0987^{*}$ & $-17.441^{*}$ & $-15.256^{*}$ \\
\hline Whole Panel & $-1.987 * *$ & $-67.352^{*}$ & $-10.271^{*}$ \\
\hline $\begin{array}{l}\text { Note: The critical values at 1\% and 5\% and 10\% are }-2.326, \text { and } \\
-1.645 \text { with structural breaks respectively. }\end{array}$
\end{tabular}

In order to exploit the panel structure of the data, we have also examined the LAPC series with panel unit root tests. Following the classification of the United Nations Statistical Division we divide the countries into five groups including Eastern African countries (Burundi, Comoros, Djibouti, Kenya, Madagascar, Malawi, Mauritius, Mozambique, Rwanda, Seychelles, Somalia, Tanzania, Uganda, Zambia and Zimbabwe) Western African countries (Benin, Burkina Faso, Cabo Verde, Cote D'Ivoire, Gambia, Ghana, Guinea, Guinea Bissau, Liberia, Mali, Mauritania, Niger, Nigeria, Senegal, Sierra Leone and Togo) Middle African countries (Angola, Cameroon, Central African Republic, Chad, Congo, Democratic Republic of the Congo, Equatorial Guinea, Gabon and Sao Tome and Principe) Southern African countries (Botswana, Lesotho, Namibia, South Africa, and Swaziland) and Northern African countries (Algeria, Egypt, Libya, Morocco and Tunisia).

Table-5 reports the empirical results provided by the LM panel unit root test without and with structural breaks. We report empirical results with none, one and two structural breaks. The LM panel unit root test is proposed by Im et al. (2005) which accommodates information of single and double structural breaks in the data. For all 3 tests (no break, single break and double break) the null hypothesis is that all series contain a unit root. For the whole panel and 2 (West Africa 
and North Africa) of the 5 sub-panel groupings the null is rejected by all 3 versions of the test using at least a $10 \%$ level. Whereas for 3 (East Africa, Middle Africa and South Africa) of the 5 sub-panel groupings the null is rejected by only 2 of the 3 versions of the test using at least a $10 \%$ level. While these latter results suggest some ambiguity of inference we believe that they indicate rejection of the null for all 3 sub-panels for two reasons. First, the majority of tests $(2$ out of 3) in each case reject the null. Second, because the tests are most powerful against the most appropriate alternative hypothesis, ambiguous results suggest that non-rejection of the null is likely due to low power because of the test being based on an inappropriate alternative hypothesis. Therefore, we interpret our results as rejecting the unit root null of the LAPC for all countries in the whole panel and regional panels. Hence, the predominant evidence from the panel unit root tests (allowing for structural breaks) is consistent with the results provided by the RALS unit root tests above.

\section{Conclusion}

The previous literature on testing for the order of integration of the APC has concentrated on developed countries and there is very little work on African countries. These papers generally demonstrate the need to account for structural breaks if the theoretically expected finding of a stationary APC is to be obtained. Obtaining the correct inference is important because, for example, the presence (lack) of mean reversion implies that shocks are likely to have transitory (permanent) effects on the APC. The aim of this paper is to test for a unit root in the APC using methods that allow for structural breaks in 50 African countries over the period 1970-2014. We therefore contribute to the literature by testing the APC's order of integration in a large number of African countries on which there is no such evidence. Another contribution is in the use of the residual augmented least squares (RALS) procedure of Meng et al. (2014) that provides for nonlinearity, asymmetry, or fat-tailed distributions in the testing process for unit roots that also allow for structural breaks.

Our results provide evidence that the LAPC is stationary around structural breaks in 44 of the 50 African countries considered (or $88 \%$ of the total sample) where the 6 countries that show evidence of non-stationarity are Equatorial Guinea, Ghana, Madagascar, Mozambique, Namibia and South Africa. These findings are broadly consistent with consumer theory that generally predicts the APC should be stationary in the sense that it is relatively constant or tends towards a constant, if there are a range of factors that can shift the constant that the APC converges to. The evident mean reversion implies that (policy) shocks are likely to have temporary effects on the APC in most African countries. The results are also in line with predictions from the literature on the "great ratios" of a stationary APC in the long-run (Romero-Ávila, 2009). Moreover, our results suggest that any empirical exercise which assumes that the APC is stationary will unlikely be subject to spurious inferences.

One of the implications of the results is that the permanent income hypothesis is true for African countries as against the Absolute Income Hypothesis. The permanent income hypothesis is known to assist in the explanation of the failure of transitory Keynesian demand management techniques to achieve its policy targets. Within the framework of the AIH, the marginal 
propensity to consume is assumed constant, and so temporary tax cuts can have a large stimulating effect on demand. However, the permanent income hypothesis framework suggests that a consumer will spread out the gains from a temporary tax cut over a long horizon, and so the stimulus effect will be much smaller. However, a permanent tax reduction will be effective because it would facilitate a permanent income increase, which would ensure that the stimulus effect will be resounding.

Moreover, the results also imply that it would be very difficult for the authorities to use policies expected by the people to alter future consumption. Unexpected changes in policy affect consumption as everything known about future changes in policy is already incorporated in the present situation. Unexpected changes in policy affect consumption only to the extent that they affect permanent income and then their effects are expected to be permanent (Hall 1987).

An additional implication of the stationarity of the APC is that monetary policy is likely be more efficient in affecting current consumption than fiscal policy (Baykara and Telatar, 2012). Through wealth effects, a loose monetary policy that reduces interest rates may stimulate asset values, including private and government bonds as well as corporate stocks or equities, thereby boosting consumption. However, stock markets in Africa are small, largely underdeveloped and illiquid and constant trading is only experienced in the few stocks that are responsible for a significant portion of the total market capitalization (Solarin and Dahalan, 2014). Therefore, to ensure that the transmission mechanism through which monetary policies affect consumption is effective African authorities need to boost the development of stock markets. 


\section{References}

Abeysinghe, T. and Choy, K. M. (2004). The aggregate consumption puzzle in Singapore. Journal of Asian Economics, 15(3), 563-578.

Amsler, C. and Lee, J. (1995). An LM test for a unit root in the presence of a structural change. Econometric Theory, 11(02), 359-368.

Ando, A. and Modigliani, F. (1963). The life cycle hypothesis of saving: Aggregate implications and tests. The American Economic Review, 53(1), 55-84.

Baykara, S. and Telatar, E. (2012). The stationarity of consumption-income ratios with nonlinear and asymmetric unit root tests: evidence from fourteen transition economies. Hacettepe University Department of Economics Working Papers, 20129.

Becker, R. Enders, W. and Lee, J. (2006). A stationarity test in the presence of an unknown number of smooth breaks. Journal of Time Series Analysis, 27(3), 381-409.

Caballero, R. J. (1990). Consumption puzzles and precautionary savings. Journal of Monetary Economics, 25(1), 113-136.

Caballero, R. J. (1991). Earnings uncertainty and aggregate wealth accumulation. The American Economic Review, 859-871

Cerrato, M. De Peretti, C. and Stewart, C. (2013). Is the consumption-income ratio stationary? Evidence from linear and non-linear panel unit root tests for OECD and non-OECD countries. The Manchester School, 81(1), 102-120.

Cook, S. (2003). The nonstationarity of the consumption-income ratio: Evidence from more powerful Dickey-Fuller tests. Applied Economics Letters, 10(7), 393-395.

Cook, S. (2005). The stationarity of consumption-income ratios: Evidence from minimum LM unit root testing. Economics Letters, 89(1), 55-60.

Davidson, J. E. H. Hendry, D. F, Sbra, F. and Yeo, S. (1978). Econometric modelling of the aggregate time-series relationship between consumers' expenditure and income in the United Kingdom. Economic Journal, 80, 661-692.

Deloitte (2014). The Deloitte Consumer Review - Africa: A 21st Century View. Retrieved from http://www2.deloitte.com/ng/en/pages/consumer-business/articles/consumer-reviewafrica.html

Duesenberry, J. S. (1952). Income, saving and the theory of consumer behavior. Cambridge, MA: Harvard University Press.

Easterly, W. and Levine, R. (1997). Africa's growth tragedy: policies and ethnic divisions. The Quarterly Journal of Economics, 1203-1250.

Elmi, Z. M. and Ranjbar, O. (2013). Nonlinear adjustment to the mean reversion of consumption-income ratio. Economic Modelling, 35, 477-480.

Fallahi, F. (2012). The stationarity of consumption-income ratios: evidence from bootstrapping confidence intervals. Economics Letters, 115(1), 137-140.

Friedman, M. (1957). A theory of the consumption function. Princeton University Press, Princeton, NJ.

Hall, R. E. (1978). Stochastic implications of the life cycle-permanent income hypothesis: theory and evidence. Journal of political economy, 86(6), 971-987.

Hattingh, D. Russo, B. Sun-Basorun, A. and Wamelen, A. (2012). The rise of the African consumer. Retrieved from http://www.mckinsey.com/global-locations/africa/southafrica/en/rise-of-the-african-consumer 
Im, K. S. Pesaran, M. H. and Shin, Y. (2003). Testing for unit roots in heterogeneous panels. Journal of Econometrics, 115(1), 53-74.

Im, K. S., Lee, J., \& Tieslau, M. (2005). Panel LM unit-root tests with level shifts. Oxford Bulletin of Economics and Statistics, 67(3), 393-419.

Jones, B. (2013). Fragile states: Taking part in Africa's inclusive growth take-off. Africa Economic Brief, 4, 1-12.

Keynes, J. M. (1936). The general theory of employment, interest and money. MacMillan, London.

Lee, J. and Strazicich, M. C. (2003). Minimum Lagrange multiplier unit root test with two structural breaks. Review of Economics and Statistics, 85(4), 1082-1089.

Lee, J. and Strazicich, M. (2004). Minimum Lagrange multiplier unit root test with one structural break. North Carolina, U.S: Department of Economics, Appalachian State University.

Lee, J. Strazicich, M. C. and Meng, M. (2012). Two-step LM unit root tests with trendbreaks. Journal of Statistical and Econometric Methods, 1(2), 81-107.

Liao, S. Huang, M. and Wang, L. (2011). Mean-reverting behavior of consumption-income ratio in OECD countries: evidence from SURADF panel unit root tests. Economics Bulletin, 31(1), 679-686.

Carrion-i-Silvestre, J. Barrio-Castro, D. and López-Bazo, E. (2005). Breaking the panels: an application to the GDP per capita. The Econometrics Journal, 8(2), 159-175.

Meng, M., Payne, J. E. and Lee, J. (2013). Convergence in per capita energy use among OECD countries. Energy Economics, 36, 536-545.

Meng, M. Im, K. S. Lee, J. and Tieslau, M. A. (2014). More powerful LM unit root tests with non-normal errors. In R.C. Sickles and W.C. Horrace (Eds.) Festschrift in Honor of Peter Schmidt. New York: Springer, 343-357.

Modigliani, F. (1986). Life cycle, individual thrift, and the wealth of nations. The American Economic Review, 76(3), 297-313.

Mosikari, T. J., \& Eita, J. H. (2017). Empirical test of the Ricardian Equivalence in the Kingdom of Lesotho. Cogent Economics \& Finance, 5(1), 1351674.

Moyo, J. Nandwa, B. Council, D. E. Oduor, J. and Simpasa, A. (2014). Financial sector reforms, competition and banking system stability in Sub-Saharan Africa. Paper presented at the IMF/DFID Conference on "Macroeconomic Challenged Facing Low-Income countries" International Monetary Fund, Washington DC, January 30-31, 2014.

Pill, H. and Pradhan, M. (1997). Financial liberalization in Africa and Asia. Finance and Development, 34(2), 7-10.

Romero-Avila, D. (2008). A confirmatory analysis of the unit root hypothesis for OECD consumption-income ratios. Applied Economics, 40(17), 2271-2278.

Romero-Ávila, D. (2009). Are OECD consumption-income ratios stationary after all?. Economic Modelling, 26(1), 107-117.

Sarantis, N. and Stewart, C. (1999). Is the consumption-income ratio stationary? Evidence from panel unit root tests. Economics Letters, 64(3), 309-314.

Shin, D. W. and So, B. S. (2001). Recursive mean adjustment for unit root tests. Journal of Time Series Analysis, 22(5), 595-612.

Solarin, S. A. and Dahalan, J. (2014). Financial development and economic growth in selected African countries: Any role for stock markets? Economia Internazionale, 67(1), 151-179.

Solarin, S. A. and Anoruo, E. (2015). Nonlinearity and the unit root hypothesis for African per capita real GDP. International Economic Journal, 29(4), 617-630. 
Tsionas, E. and Christopoulos, D. (2002). Non-stationarity in the consumption-income ratio: further evidence from panel and asymmetric unit root tests. Economics Bulletin, 3(12), 1-5.

United Nations (2016). United Nations database. Retrieved from http://www.un.org/en/databases/.

Wagner, M. (2008). The carbon Kuznets curve: a cloudy picture emitted by bad econometrics? Resource and Energy Economics, 30(3), 388-408.

World Bank: World Development Indicators (2016). Retrieved from www.data.worldbank.org

Zafar, A. (2007). The growing relationship between China and Sub-Saharan Africa: Macroeconomic, trade, investment, and aid links. The World Bank Research Observer, 22(1), 103-130. 